\title{
"No Man Has the Right to Fix the Boundary to the March of a Nation": Fixing the Boundaries of Irish Nationalism, 1882-85
}

"Personne n'a le droit le fixer de limite à la marche d'une nation": délimiter les frontières du nationalisme irlandais, 1882-1885

\section{Frank Rynne}

\section{(2) OpenEdition}

\section{Journals}

Electronic version

URL: http://journals.openedition.org/rfcb/3714

DOI: $10.4000 /$ rfcb.3714

ISSN: 2429-4373

Publisher

CRECIB - Centre de recherche et d'études en civilisation britannique

\section{Electronic reference}

Frank Rynne, " "No Man Has the Right to Fix the Boundary to the March of a Nation": Fixing the Boundaries of Irish Nationalism, 1882-85", Revue Française de Civilisation Britannique [Online], XXIV-2 | 2019, Online since 19 June 2019, connection on 09 July 2019. URL : http:// journals.openedition.org/rfcb/3714; DOI : 10.4000/rfcb.3714

This text was automatically generated on 9 July 2019.

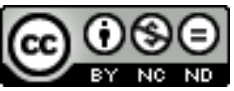

Revue française de civilisation britannique est mis à disposition selon les termes de la licence Creative Commons Attribution - Pas d'Utilisation Commerciale - Pas de Modification 4.0 International. 


\title{
"No Man Has the Right to Fix the Boundary to the March of a Nation"1 : Fixing the Boundaries of Irish Nationalism, 1882-85
}

\author{
"Personne n'a le droit le fixer de limite à la marche d'une nation": délimiter les \\ frontières du nationalisme irlandais, 1882-1885
}

Frank Rynne

\section{Introduction}

1 In February 1882, W.E. Gladstone, then during his second premiership, came to believe that if the majority of Irish MPs demanded Home Rule and the British parliament rejected it out of hand, then the state, or the union of the United Kingdom, might be threatened. ${ }^{2}$ By March 1885, Gladstone had come to believe that there would never be "any moral obligation to the Irish nation in the Act of Union". ${ }^{3}$ Gladstone was influenced by a speech by William O'Brien, MP, leader of the Irish National League who in the period made forceful speeches on the Irish need for democracy referencing its long history of resistance to English rule. At Mallow in February 1885, O'Brien claimed that "the power of the people is now practically supreme" and that "the day of Irish Nationality - the coming of Irish Nationality is as certain as the coming of to-morrow's sun". ${ }^{4}$

2 In the period between February 1882 and the general election of 1885, Irish political organising under the Home Rule banner was streamlined under its leader Charles Stewart Parnell. In 1885, for the first time, a decisive number of Irish Home Rule MPs were returned in the November-December general election ensuring that the Irish question was one that would have to be addressed by parliament, whichever of the two main United Kingdom parties were to hold government. In the 1885 election, the Home Rule party won 86 seats; 85 of the 103 Irish seats and even one seat in a Liverpool constituency 
which returned T.P. O'Connor for the Home Rule Party. Thus, a united Irish party held the balance of power between the Tories with 249 seats and the Liberals under Gladstone with 335 MPs. $^{5}$

However, Home Rule for Ireland was a divisive subject in the United Kingdom - not just between parties but also internally amongst both the Liberals and the Conservatives. History had shown that holding the balance of power in parliament did not guarantee the prospect of devolution, repeal or independence for Ireland. However, what was remarkable in Irish politics was the ability of Parnell and his machine to forge a united Irish party at Westminster where, so far, other Irishmen had successively failed to maintain unity of purpose. Throughout the three decades following the Great Irish Famine of 1845-52, Irish nationalist representation in parliament was weak and disparate. Its weakness was due to the fact that it was almost impossible for an Irish nationalist party to act as one. In 1852, an attempt by the Independent Irish Party to hold the balance of power in Westminster by remaining united in the midst of divisions in the Whigs and Tories proved initially successful but the party collapsed when John Sadleir and William Keogh accepted government offices. ${ }^{6}$ This betrayal of a pledge to remain aloof from alliances with British political parties was used as justification by the founders of the Advanced Nationalist Fenian movement to validate their aim of achieving a united and republican Ireland through force of arms. Parnell's greatness as a political leader was his ability to harness disparate forces in Irish politics and society, both clerical and secular, and his legacy was an Irish party that would eventually achieve the parliamentary acceptance of Home Rule for Ireland twenty-one years after his death. This article will focus on the background to the ascent of Parnellism and the circumstances between 1882 and 1885 that brought Parnell and his party such success at the election of 1885 .

\section{Parnell's rise: the early days of Home Rule and the first Land War}

4 Founded 1858 as the Irish Revolutionary (later Republican) Brotherhood (IRB) and the Fenian Brotherhood in the United States, the Fenian movement became an abiding fixture of Irish nationalist politics for more than half a century. Despite its abysmal failure at armed revolution, its various organisations became a central element in Irish political life especially following the failed 1867 rising. While the above mentioned Sadleir and Keogh episode had a direct influence on the Fenian movement's advocacy of a revolutionary rather than a constitutional approach to achieving an independent Ireland, it was its American base and its ability to raise funds and proselytise for a united independent Ireland that ensured its importance. Its adherents' imprisonment in the late $1860 \mathrm{~s}$ garnered public sympathy and led to civil and political organisations that advocated Home Rule for Ireland. The suppression of the Fenian movement from 1865 led to a growing popular sympathy for their nationalist ideal of an independent Ireland. This ideal was not wholeheartedly embraced by all in Ireland, but demands for greater independence began to dominate mainstream Irish politics from the early 1870s. Isaac Butt, the founder of the Home Government Association in 1870, had been a barrister for IRB prisoners in the mid-1860s and rose to political prominence in the Amnesty movement that sought the release of Fenian convicts from $1869 .{ }^{7}$ In his 1870 pamphlet, Irish federalism, its meaning, its objects and its hopes, he proposed a "Federal Union" for Ireland. ${ }^{8}$ In 1867 Canada had been granted dominion status with a federal structure. 
However, Ireland's constitutional case was different: though administered in a quasicolonial manner, it was nonetheless part of the United Kingdom. The early days of the Home Rule agitation in Ireland brought together incongruous alliances with Fenian cadres supporting Home Rule Tories against Gladstonian Liberal candidates who had the support of the Catholic clergy. This period also saw members of the IRB Supreme Council like Joseph Biggar and Thomas O'Connor Power standing successfully for election to the House of Commons despite their movement's eschewing participation in parliamentary politics. However, in 1876 the IRB Supreme Council voted to remove its participatory support for the Home Rule movement. ${ }^{9}$ Butt's Home Rule League founded in 1874 had both conservative and radical/revolutionary wings, the latter including Fenian-aligned MPs such as Biggar and O'Connor Power. Thus, it was relatively incoherent and ineffectual as a political force. ${ }^{10}$ However within its ranks there was a potential that was seized upon by ambitious politicians and revolutionaries alike.

5 In 1875 the radical wing of Butt's party was joined at Westminster by the young MP for Dublin, the Protestant Co. Wicklow landlord Charles Stewart Parnell. ${ }^{11}$ The years between 1875 and 1882 saw Parnell and a Fenian nexus change the shape of Irish politics and begin to change Irish nationalist representation at Westminster. Firstly, Parnell successfully aligned himself with the international Fenian movement, namely the larger and more influential offshoot of the Fenian Brotherhood, Clan-na-Gael. Though also prone to splits and infighting, Fenianism in the United States was a source of financial muscle. In 1878, Parnell's ascendency in Irish politics was cemented when John Devoy, a leader of the Clanna-Gael telegrammed the president of the IRB, Charles Kickham, announcing a dramatic change in Fenian orthodoxy. He also immediately published the five conditions on which nationalists would support Parnell in what became known as the New Departure. ${ }^{12}$ These conditions included abandoning a federal solution in favour of "a general declaration in favour of self-government", "agitation on the land question" seeking peasant proprietorship, " exclusion of sectarian issues from the platform", "Irish members [of parliament] to vote together on all home and Imperial questions" while resisting coercion, and offering support to "all struggling nationalities in the British Empire or elsewhere". ${ }^{13}$ This new departure led directly to the formation of the Irish National Land League (INLL) in October 1879 and the subsequent Land War 1879-82, which brought the rule of law in Ireland to a state of crisis.

\section{The Irish National Land League and the first Land War}

6 The Irish National Land League was founded in October 1879 with Parnell as its president. The governing body was thoroughly Fenian and from early 1880 it started sub rosa efforts to insert Parnellite and Land League-favoured candidates as parliamentary candidates for the Irish Party at the general elections that year. ${ }^{14}$ Following that election Land League branches were started throughout rural Ireland even making inroads in the Orange heartlands of Ulster through the summer, autumn and early winter of $1880 .{ }^{15}$ While ostensibly a tenant right movement, it was a movement organised at a grassroots level by members of the IRB and was largely financed by separatists in the United States. This New Departure was a departure for Advanced Nationalists, who had previously advocated shunning parliamentary and constitutional politics. By financing and organising the Land League movement and in aiding Irish politicians headed by Parnell, the aim was to further the cause of an independent Ireland under the Home Rule banner. In the period of the first Land War, hundreds of thousands of pounds flowed into Land League coffers 
from the United States. ${ }^{16}$ Despite opposition from the ruling body of Irish Fenianism, the IRB Supreme Council, Land League organisers took their lead from the American wing of the Fenian movement and many Irish Americans returned to Ireland, taking an active part in INLL activities. ${ }^{17}$ Land League meetings and posters promoted Advanced Nationalism while in Land League strongholds violence and intimidation was often aimed at landlords who held local administrative functions. Thus, the Land League was also a giant propaganda machine promulgating the ideas of Advanced Nationalists, humiliating and harassing local government office-holders, as it promoted an independent Ireland free from what was considered to be English tyranny. ${ }^{18}$ This approach proved successful and the rhetoric and organising structure of the Land League owed its strength to the organising abilities of grassroots Fenianism. However, despite many parts of rural Ireland becoming ungovernable, Ireland did not rise up in rebellion against British rule. Yet the tone had been set and as will be seen below, this strand of Advanced Nationalist rhetoric became central to the success of Irish political figures demanding Home Rule in subsequent years.

7 In order to combat the breakdown of law and order that followed the organisation of local INLL branches, Gladstone's Liberal government was forced to adopt the most illiberal of policies including, from March 1881, the suspension of habeas corpus. ${ }^{19}$ However, Gladstone had a long history of defusing Irish tensions, as evidenced by his disestablishment of the Church of Ireland in 1869, the 1870 Land Act and the amnesty of Fenian prisoners. ${ }^{20}$ The Land Act of 1881, coupled with the use of draconian powers to crush militancy, seemed to be a perfect solution politically. However, despite the fact that the Land Act of 1881 gave tenants "the Three Fs" the Land League demanded (fair rent, fixity of tenure and free sale of their interest in their holdings), "Crime and Outrage" continued in Ireland. ${ }^{21}$ By October 1881 Parnell and other leaders of the Land League were imprisoned and despite his reservations he signed the "No Rent Manifesto" calling on tenants to abstain from the relief provided by the Land Act and to withhold all rent payments from their landlords. ${ }^{22}$ At this stage in his career Parnell had obtained the status of a patrician rebel leader unbowed by the state and un-bowing to the same illiberal use of draconian coercive legislation that IRB-associated prisoners wore as a badge of honour, calling themselves "Ex-Suspects" on their release from prison. ${ }^{23}$ However, while incarcerated Parnell was forced to sit on the sidelines as Gladstone's Land Act took effect. From March and into April 1882, he sought to solve this situation by appealing through intermediaries to Gladstone and thus beginning the next phase of his political career.

\section{“Kilmainham Treaty", 1882}

From March 1882, after negotiations through intermediaries such as William O'Shea MP, O'Shea's wife and Parnell's lover Katherine O'Shea, and Justin McCarthy MP, the government agreed that Parnell and the other suspects should be released in return for concessions on both sides. ${ }^{24}$ The deal negotiated between Parnell and Gladstone became known as "The Kilmainham Treaty". Though not a treaty or even a signed agreement, Gladstone agreed to release the prisoners arrested under the 1881 Protection of Person and Property (Ireland) Act and introduce legislation whereby the government would compensate landlords for arrears and allow tenants who had owed arrears having followed Parnell's advice in withholding their rents, to benefit from the provisions of the 
Land Act. Parnell agreed that if the issue of arrears was settled he would "co-operate fully for the future with the Liberal Party in forwarding Liberal principles and measures of general reform". ${ }^{25}$ In effect, Parnell agreed to cooperate with the British government in slowing down the agitation in Ireland and aiding in the restoration of law and order. ${ }^{26}$ It must be noted that the rhetoric of the Land League and the campaign was one which attacked Britain's role in Irish affairs in a virulent fashion. The government, landlords and the oligarchy were decried by politicians on Land League platforms throughout most of Ireland. Thus, this agreement with Gladstone could have proved to be the death knell of Parnell's career and indeed of Parnellite politics. However, in the intervening month and years, Parnell's star rose and the Irish Parliamentary Party with its demand for Home Rule became the dominant political force in Ireland.

On 2 May 1882, Parnell and two other MPs, John Dillon and J.J. O Kelly, were released, prompting the resignation of the Chief Secretary of Ireland and cabinet member, W.E. Forster. ${ }^{27}$ Forster's resignation was announced in the House of Commons at the same time as the announcement that the Coercion Act would be allowed to lapse, and that ordinary law would be strengthened instead. The Commons was in uproar over the announcement that Davitt - another leader of the Land League who, like O'Kelly, was a Fenian or former Fenian - was being released and that Forster's replacement would be Lord Frederick Cavendish, viewed as a moderate..$^{28}$ On 4 May while Forster was giving a statement explaining his reasons for resignation from the cabinet, which went further than his disagreement with cabinet colleagues over the release of the three MPs, Parnell entered the House to loud cheering from his Home Rule comrades. ${ }^{29}$ On 6 May Davitt was met on his release from prison by Parnell and John Dillon. That evening in Dublin the newly appointed chief secretary, Cavendish and his under-secretary, an Irish Catholic, T.H. Burke, were strolling towards the Vice-regal lodge in Phoenix Park when they were set upon by a group of men with IRB associations named Irish National Invincibles and were hacked to death with surgical knives. ${ }^{30}$ The Phoenix Park Murders created a sense of outrage and shock but Gladstone was convinced that Parnell was genuinely not complicit in the murders. The latter was evidently deeply shaken by the assassinations, though there is speculation as to whether he had any prior knowledge of such plots. ${ }^{31}$

\section{Advanced Nationalism, the Irish National Land League and the National League}

As noted above, the Fenian movement was prone to infighting. It is possible to view the public actions of Advanced Nationalists in supporting the INLL as being incompatible with Fenian organising, but it must be borne in mind that secret revolutionary movements can allow themselves great latitude of action and may be adepts at sublimation. Sublimation remains a central feature of terror movements to this day. It is notable that in the 1880 s, John Devoy of Clan-na-Gael supported Parnell and the open Land League while he was also close to figures who were engaged in the dynamite campaign, which was organised by supposedly rogue elements within the Fenian movement and was encouraged by Jeremiah O'Donovan Rossa. ${ }^{32}$ While Rossa revelled in the public outcry which followed dynamite outrages, the Fenian movement was divided and ambiguous in its attitude to what was termed "skirmishing", despite the public backlash and anti-Irish feeling it triggered in England. ${ }^{33}$ Niall Whelehan has questioned whether the subscribers to funds for various Irish causes differentiated between physical force or purely political activities - be they 
the Land League, the No Rent fund or, funds for dynamiters - as collected through Patrick Ford's American newspaper The Irish World. According to Whehelan, they may not have viewed them as "separate projects" ${ }^{34}$ This ambiguity underpins an aspect of Irish politics where rhetoric and substance may diverge. For the Parnell movement, as it transformed itself from a revolutionary to a purely constitutional organisation, Irish American support was essential. Despite assassinations and the murder of landlords, Gladstone remained committed to the programme worked out with Parnell. However, the former activity did nothing to harm the political movement in the eyes of American supporters. Conversely, according to T.W. Moody, Parnell had called off the Land War, “ snuffed out" the radical Ladies' Land League and won great concessions for 130,000 poor tenants in arrears at government expense..$^{35}$ Moody noted that Parnell's Land League programme was essentially realised over the coming years, with both tenants, from 1885 and leaseholders from 1887 being advanced $100 \%$ of the purchase price of their land by the government through various land acts notably the Ashbourne Act of $1885 .{ }^{36}$ By moving on from agrarian agitation, Parnell was able to concentrate on parliamentary politics with the focus on Home Rule instead. Yet, the political movement could not afford to be too distant from the radical rhetoric of Advanced Nationalists or it would have risked losing the vital support of the Irish Americans.

11 Alvin Jackson maintains that the Phoenix Park Murders and the settlement of the rent arrears issue allowed Parnell an opportunity to side-line the radical elements of the old Land League as the IRB and the Fenian movement were on the backfoot due to the universal condemnation and shock the assassinations provoked. Jackson states:

Rather the murders in temporarily discrediting the hardline position, permitted Parnell to reconstruct the national movement without the burden of his radicals and along the lines of his own political perspectives. ${ }^{37}$

On 17 October 1882 a new league, The Irish National League (INL) was founded. ${ }^{38}$ The same month Parnell took hold of all the Land League funds, which were still held by Patrick Egan in Paris, thus keeping them out of the grasp of more radical elements. Paul Bew noted that Parnell replaced the "existing national structures" with a more centralised organisation. ${ }^{39}$ Bew stated that Parnell dedicated himself to Westminster politics, appearing only twice in the West of Ireland, the heartland of the old Land League agitation, between October 1881 and January $1885 .{ }^{40}$ The Irish National League was a very different organisation to the Land League. Its first objective was "national self-government" with "land law reform" taking second place. ${ }^{41}$ It was an organisation dominated by members of parliament who were originally supposed to nominate sixteen of the fortyeight board members, with the other thirty-two to be nominated by county conventions. However, this never came to pass and the organisation remained under the control of the original organising committee of thirty members which would eventually be dominated by twenty MPs. ${ }^{42}$ The INL essentially took on the credibility of advanced nationalism forged by the Land League and harnessed it for a purely constitutional and more conservative organisation. However, despite its democratic appearance, Conor Cruise O'Brien noted that the functioning of the INL was thoroughly autocratic. This gave Parnell and his close cohorts complete control of what became a "smooth running national electioneering" machine. ${ }^{43}$

13 The Irish National Land League had both practical and propaganda aims, it also organised a political machine at grassroots and local level. However, the INLL had been outlawed in October 1881. Therefore, by reorganising the national movement the INL was able to 
continue using the INLL's base but maintained it under the strict control of a central organisation. The aspirational rhetoric of the "extremist wing" of Parnellism was also maintained. Conor Cruise O' Brien referred to a comment in The Nation newspaper in 1882, which stated that: "Some people think that the Irish party are not doing their duty unless they are perpetually engaged in hostilities with the government or with the House". ${ }^{44}$ One of the greatest practitioners of propagandistic militancy and later leader of the second land war, William O'Brien, maintained a virulent stream of attacks on the British government and individuals through the pages of the newspaper United Ireland. The newspaper was originally the organ of the INLL, and Parnell had appointed O'Brien editor in 1881. O'Brien had been the author of the 1881 "No Rent Manifesto" and was elected MP for Mallow in a by-election in $1883 .{ }^{45}$ His IRB background and his fiery rhetoric, entirely uncritical of Parnell and Parnellism, satisfied the militant wing of Irish nationalism both through the pages of United Ireland and the frequent court cases for libel and seditious libel provoked by the organ's weekly output. From 1882 to 1884, Parnell was mostly in England and Michael Davitt, resided in the United States According to O'Brien, in those years "United Ireland had to run the all but exclusive risk of keeping the torch of public liberty alight" ${ }^{46}$ Its policy was thus to maintain an onslaught of virulent propaganda. O'Brien stated in his memoirs that: "The paper only survived the prosecution for one seditious libel by replying with a dozen fresh ones" ${ }^{47}$ The fact that United Ireland was prosecuted for publishing articles which were claimed to have

[...] the intention of bringing the Government into hatred and contempt, and for the purpose of creating hatred and ill will between the subjects of her Majesty the Queen, and for the further purpose of causing disaffection and discontent in the country $^{48}$

aided Parnellism in maintaining its credibility with Irish Nationalists in the United States and Ireland in the years leading up to the 1885 general election. In the 1882 case, O'Brien had accused the government of "judicial murders" in an article about the infamous Maamtrasna murders of five members of one family..$^{49}$ It is also notable that despite the knowledge among senior Fenians in the United States that the Catholic Church, nervous of Fenianism, was necessary to create a "universal order", the president of the Fenian Clan-naGael, Alexander Sullivan, was also president of the American wing of the National League from 1883-4. ${ }^{50}$ Though Parnell had harnessed the full effect of his radical credibility towards what was a constitutional rather than a revolutionary movement, the Church was another matter and it was also masterfully brought into the Parnellite fold.

\section{Parnellism embraced by the Irish Church}

14 To create the universal order which John Boyle O'Reilly deemed was possible in 1883, the Catholic Church was an essential collaborator which needed to be won over to Parnellism to achieve the political hegemony it effected in 1885 . To this end Parnell skilfully manoeuvred. R.F. Foster noted that in 1880 the Catholic hierarchy was extremely reluctant to support the demands of the Land League with only five of the twenty-eight bishops supporting its demands in the 1880 general election. ${ }^{51}$ However, as Foster wryly highlighted:

Priests were another matter however: fourteen of the sixty foundation members of the League were clerics. And, as on other occasions in Irish history, the Church adroitly changed its footing to follow the way its flock was going. ${ }^{52}$ 

Protestant origins. Its first leader was the Protestant barrister Isaac Butt and its Land League incarnation was a compact with Fenianism, which, as an oath bound movement, was contrary to Catholic doctrine. However, Parnell though Protestant by birth, was likely agnostic and for the Irish hierarchy, according to R.F. Forster, this was "preferable to the wrong kind of devoutness". ${ }^{33}$ The relationship between some Home Rule MPs and English radicals was another issue of concern to the Church. According to Alan O'Day, prior to 1882, "a section of the Parnellite leadership paid scant heed to clerical opinion". ${ }^{54}$ In 1880 , the leader of the Secular Society, Charles Bradlaugh, was elected MP for Northampton and queried the religious oath of allegiance MPs were required to take in order to sit in the House of Commons. Amongst those he counted as supporters were Irish Party MPs. However, this changed from 1882 and indeed antagonism towards English radicalism was notable in the Home Rule leadership after Kilmainham. One of the main contentious issues was the Radicals' support for non-denominational education, which "was anathema to the Catholic Church". ${ }^{55}$ Radicals drew support from non-conformist Protestants and were, according to O'Day, "in general hostile to the Catholic Church". ${ }^{56}$ However by mid-1882 the Parnellites had become what Alan O'Day termed "an orthodox Catholic mouthpiece" to such an extent that when, in 1883, an order was issued from Rome telling bishops and priests to refrain from associating with the National League, the reaction from the Catholic oriented Irish newspaper The Nation was blunt: "we shall stand for the national rights and liberties of Ireland against Rome" ${ }^{57}$ In May 1883, Papal prohibition of a fund to personally aid Parnell, who was in financial difficulties, was ignored by "key leaders of the Irish Church". ${ }^{58}$ One such cleric, the Archbishop of Cashel, Dr. Croke, received a papal reprimand from Leo XIII for actively supporting William O'Brien's candidacy in the Mallow by-election in $1883 .{ }^{59}$ The same year when the annual debate on funding for the multidenominational Queen's Colleges in Ireland was held at Westminster, the only Irish members present were the Cork MP and convert to Catholicism, Col. Colthurst, and Parnell who gave a "Parnellite stand against the Queen's Colleges". ${ }^{60}$ The fact that the Catholic Church moved firmly behind Parnell despite missives and reprimands from Rome indicates that the Irish hierarchy considered the Holy See to be influenced by British overtures and was out of touch with purely Irish questions. By October 1884, the hierarchy had entrusted "the care of Irish Catholic educational interests to the Irish party and its Protestant leader" Parnell. ${ }^{61}$ This bond between Parnellism and Irish Catholicism was to have far reaching effects for modern Ireland. The consequences were cemented by the dominance of Parnellism in the general election of 1885. However, the flirtation was to have disastrous consequences for Parnell when he was named in the O'Shea divorce petition in 1890 .

\section{Parliament}

Between 1880 and 1883, Parnellite MPs intervened in parliamentary debates on a wide range of issues, managing to keep Irish affairs to the fore of debate and questions in the House. However, from 1883, with greater use of the committee system to deal with specific issues, Parnellites took advantage of this reorganisation "for more effective obstruction and harassment on nearly every topic before the House of Commons." ${ }^{62}$ Question Time, a period when questions could be asked before the House's Order of the Day was announced, provided an opportunity for Irish MPs to insert themselves into Commons

Revue Française de Civilisation Britannique, XXIV-2 | 2019 
affairs on thousands of occasions. ${ }^{63}$ Alan O'Day's research shows that in the 1884 and 1884-5 parliamentary sessions Parnellites posed more than 2,800 questions at Question Time. ${ }^{64}$ O'Day notes that this activity in Parliament aided the myth of Parnellites being a party of obstruction but members increasingly became involved in broader parliamentary affairs taking positions on issues such as the tax on tea, public health and safety and taxation. ${ }^{65}$ While Butt's Home Rule party in the 1870s had pledged to remain "aloof and independent of all party combinations", Parnell introduced a principle of "majority rule" on assuming leadership of the party in $1880 .{ }^{66}$ The latter opened the way for the Home Rule Party to form alliances and thus potentially play kingmaker in the United Kingdom parliament. O'Day states that from 1882 Irish members were consulted in private on certain legislative matters and some were "given patronage and others were accorded favours, while in public they were allowed to abuse the Liberals at will." ${ }^{67} \mathrm{James}$ McConnel states that: "after 1882 a number of senior Parnellites, including Parnell himself, sought and received government situations on behalf of their constituents". ${ }^{68}$ In 1884 the Liberals introduced a Franchise bill, which would increase suffrage to all males who paid rent of, or who held land valued, at $£ 10$. The effect was to increase the Irish electorate from 200,000 to more than 600,000 . Before the passage of the Representation of the People Act of 1884, Parnell expected to win 75 of Ireland's 103 Westminster seats, while after its passing he expected to win 85 seats. ${ }^{69}$ This increase in Parnell's electoral possibilities was reinforced with the 1885 Redistribution of Seats Act, which altered constituencies throughout the United Kingdom. ${ }^{70}$ While not speaking in parliament in support of the bill, the Irish Party did support it with their votes. ${ }^{71}$ In this period the old Liberal Party in Ireland was seen as finished. However the Liberal Party at Westminster came to see the Irish Party as being essentially Liberal..$^{72}$ To woo Irish party support, the two main British parties had to maintain a fine balance between according a level of autonomy to Ireland such as a measure short of Home Rule - for instance, proposing the broadening of local government - and the issue of law and order, which inevitably revolved around the use of coercive legislation. ${ }^{73}$ In 1884 , the then Radical Liberal Joseph Chamberlain proposed a central local government board. The issue of greater powers for local authorities and of even self-government was on the table but as of September 1885, when Gladstone published his manifesto, he could not commit to a definite course of action. Noting the problem of getting parliamentary support for such measures, he stated:

To maintain the supremacy of the crown, the unity of the empire, and all the authority of parliament necessary for the conservation of that, is the first duty of every representative of the people. Subject to this governing principle, every grant to portions of the country of enlarged powers for the management of their own affairs is, in my view, not a source of danger, but a means of averting it, and is in the nature of a new guarantee for increased cohesion, happiness and strength. ${ }^{74}$

Gladstone was at once acknowledging a need for concessions to Irish Party demands, but also noted the fear that giving too much to Ireland would threaten the unity of the British Empire. But what would compel the United Kingdom to give Ireland its independence or just Home Rule? Parnell warned earlier in September 1885 that if British politicians persisted in the belief that granting Home Rule to Ireland would lead to the disintegration of the Empire then the Irish party would have no reason to exist. He was reported as having said that if the constitutional will of the Irish people was ignored then constitutionalists would be redundant and other men would fill the breach and do the job for them..$^{75}$ Other men can only mean Advanced Nationalists or physical force men. This type of rhetoric had a dual purpose, to warn British politicians that there was a real 
danger of revolt should they not accept the will of the Irish voters, and also to reassure and rally the advanced nationalist wing prior to an election that would be dominated by a united front for Home Rule combining clerics, Fenians and generally the Catholic populace. In November 1885 prior to the general election, Parnell was to prove to be his own man and not a Liberal pawn when he urged Irish voters in the United Kingdom to vote Conservative. ${ }^{76}$ That Parnell would appear to abandon his Liberal alliance was in keeping not just with political circumstances but also his own previous pronouncements. On St. Patrick's Day 1884 he stated in a speech at a banquet in London that he did not “[...] depend upon any English political party. I should advise you not to depend upon any English political party." "77 In the same speech, he stated that he knew of no country which governed another to be aware of the "real necessities" without being "compelled to do so". ${ }^{78}$

\section{The General Election}

In June 1885 Gladstone's second ministry was dissolved and a minority government led by Lord Salisbury was installed. The general election was held from the last week of November until mid-December. According to R.F. Foster

Parnell's 'National League' for getting out the vote was ostentatiously referred to by some Tories as the 'Land League': in a way, they had a point. Though purely a political machine, it inherited the moral authority of the earlier organisation. The county conventions that chose candidates acted under direction from above; Parnell monopolised the power of choosing the candidates, only delegating as suited him. ${ }^{79}$

The National League erupted into action. In January 1884, it had 242 local branches, which grew to 592 within a year, 862 by July 1885 and to 1,262 branches by January $1886 .{ }^{80}$ Home Rule candidates were chosen by county conventions. As has been noted above, the organisation remained completely autocratic and was under the direct control of Parnell and a small group of MPs. Controlling the choice of candidates gave Parnell and his inner circle the ability to select men who would later follow the party line at Westminster. Based on his study of thirty-two county conventions, Conor Cruise O'Brien noted that they were typically made up of "150 laymen and 50 priests" meeting in a hotel and then entering a private session under the chairmanship of an MP. ${ }^{81}$ It was in these private sessions that candidates were chosen and thereafter a public meeting usually chaired by a priest declared the chosen candidate and sang the praises of the candidates that had "withdrawn their names in the interests of unity". ${ }^{82}$ Candidates had in fact been chosen in advance by a small group of MPs meeting at Morrison's Hotel in Dublin. ${ }^{83}$

In September 1885, J.J. O'Kelly, MP, wrote to John Devoy on the subject of the upcoming election and noted that the backing of the bishops was " $a$ source of great immediate strength" but he feared that this could backfire later and that the attitudes of some Advanced Nationalists were aiding the power of the "Church Party" in the nationalist movement. ${ }^{84}$ O'Kelly appeared to warn Devoy noting that any Advanced Nationalist who did not support the Home Rule Party could be held "responsible before history for the failure of a movement which if allowed to develop rationally promised to make a real and what is better a permanent revolution in Irish politics." ${ }^{85}$ O'Kelly was aware that some of the candidates chosen may not suit Clan-na-Gael ideals, but he urged Devoy to have faith in the political movement for the time being and keep the hardliners in check. Notable amongst those who distrusted the clerical influence was Michael Davitt, who feared that priests would 
choose their own candidates.$^{86}$ O'Kelly noted that Advanced Nationalists' funds sent over the past five years were essential but assured Devoy that most were used for relieving the "victims of the Land War". ${ }^{87}$ The letter went on to ask Devoy to write to "his friends" and get them to "join in in an effective manner" in the upcoming elections as the organisation was determined to get people elected who "can be depended on to lay the foundation of Irish SelfGovernment on a secure and lasting basis". ${ }^{88}$ The latter reference was clearly not alluding merely to Home Rule but rather to total independence from Britain. O'Kelly went on to say that: "For good or evil the Parliamentary party are the appointed spokesmen of the Irish Nation for the moment, they are therefore entitled to call on all nationalists for help and support." ${ }^{89}$ Two subsequent letters from O'Kelly in October and December raised the subject of choosing candidates other than the ones wished for by Devoy and the Advanced Nationalists. O'Kelly assured Devoy that Parnell desired to "look after your friends [...] where it is possible" but that they could not risk losing seats "at this critical juncture". ${ }^{90}$ It is clear from this correspondence that the Parnellite leadership was maintaining an astute balancing act to maximise both the support of the Catholic Church and of the Irish revolutionaries. It is also clear from Parnell's statements noted above that he publicly allowed the Advanced Nationalists to believe that if constitutional methods failed, they would have a legitimate right to use other means in order to achieve national independence. The Advanced Nationalists were further appeased by the number of supposedly ex-Fenians who stood for and thus were guaranteed to be returned in the 1885 general election. James McConnel in his essay "'Fenians at Westminster': The Edwardian Irish Parliamentary Party and the Legacy of the New Departure" charts the involvement of Fenians as MPs elected in post-Land War by-elections and at the 1885 general election. These included William O'Brien, editor of United Irishman and several others who were well known for both their activities in the Land War and speeches espousing the ideals of revolution. ${ }^{91}$ It is likely that more of the candidates that were elected were Advanced Nationalists than has previously been recognised by historians. It is also clear that many did not renounce their allegiance to the Fenian movement merely by entering parliament, despite the IRB's official stance on parliamentary service..$^{92}$ As McConnel noted, James J. O'Kelly was probably still in the IRB in $1891 . .^{93}$

21 Parnell and his party were triumphant at the ballot of 1885 . The Liberal Party in Ireland was wiped out. Of the 103 seats in the country the Home Rulers secured 85. They also won a Liverpool seat, won by the Fenian-connected T.P. O'Connor. Of the 79 seats contested in Ireland, they won 65 . A further 24 were not contested and 20 Home Rulers were returned unopposed with the other four uncontested seats going to the Conservatives..$^{94}$ In Cork City, which elected two MPs on the same ballot, Parnell and T.M. Healy were returned with 6,716 and 6,536 votes respectively from an electorate of 8,084. Their opponents, Mr. Pike and Capt. Bainbridge, got 1,464 and 1,401 votes. ${ }^{95}$ Nationally, of 438,001 votes cast, 290,005 or $66.21 \%$ were for Parnellites, 109,393 for Conservatives or Conservative Unionists (24.97\%), 35,713 (7.24\%) for Liberals or Liberal Unionists and 2,880 (0.65\%) for independent nationalists. ${ }^{96}$ While the combined nationalist vote was two thirds of the votes cast, they won $82.5 \%$ of the seats in the country. To achieve this, Parnellites used a combination of Catholic clerical support and support from the separatist Advanced Nationalists. In 1886, Gladstone, now back in power, introduced his ill-fated Home Rule bill but the effects of the 1885 general election were to be felt in Ireland for generations. Brian Walker has shown that while Presbyterians and Catholics in Ulster had often found common cause in electoral politics before 1885, "by 1886 Protestants and Catholics were clearly divided into opposing camps". ${ }^{77}$ While Parnell with his 86 MPs managed to get 
Gladstone back into power, Home Rule split the Liberal party, ensuring a Conservative government following the polls in July $1886 .{ }^{98}$ Though Parnellism was a movement built on a foundation of nationalism and agrarian revolt its embrace of the Catholic church and the Catholic Church's ability to turn a blind eye to the advanced nationalist wing placed the Catholic Church at the heart of nationalist politics. R.F. Foster noted that the "Ulster's forms of sectarianism and Unionist politics, already in existence, were set hard by the dynamic events of the 1880s." "99 The 1885 general election was key to this cementing of sectarianism in Ireland.

\section{Conclusion}

The general election of 1885, though a monumental achievement for Parnell and Parnellism in terms of electoral success, must be viewed as a decisive event in the hardening of divisions in Ireland. The fact that the Catholic Church, which had long been an enemy of Fenianism and the Fenian movement, was now fully committed to a political movement, which still owed its existence to the financial muscle of North American Advanced Nationalists, hardened and increased sectarian divisions in Ireland. The Fenian movement, by assisting in this political experiment, undermined its own previous nonsectarian republican stance. The politics of expediency, and business as usual, the propping up of British political parties on the promise of Home Rule may be viewed as politically responsible, respectable and convenient but short of achieving Home Rule immediately. The development of Parnellism from the Land War to 1885 cemented long existing divisions in the fabric of Irish society. By wiping out the Liberal Party in Ireland all that was left were two stark camps, one Conservative and Unionist, the other Catholic and Nationalist. Despite his Protestant background Parnell's political manoeuvrings could only have been successful had Home Rule been achieved in the immediate aftermath of the 1885 general election. Likewise, the gamble that Advanced Nationalists of the Fenian Movement took by betting on parliamentarianism ensured that their aim of a united independent Ireland became as mythological as the Fianna from whom they derived their name.

BIBLIOGRAPHY

\section{Primary Sources}

\section{Archival Sources}

National Archives of Ireland, Irish National League papers, 1879-1889. 


\section{Acts of Parliament}

The Irish Church Act 1869, 32 \& 33 Vict., c. 42 [26 July 1869].

Landlord and Tenant (Ireland) 1870, Vict., 33 \& 34, c.46 [1st August 1870].

Protection of Persons and Property (Ireland) Act, 188144 Vict. c.4 [2. Mar 1881].

Representation of the People Act 1884 (48 \& 49 Vict. c. 3) [6 Dec. 1884].

Redistribution of Seats Act 1885 (48 \& 49 Vict., c. 23) [25 June 1885].

\section{Parliamentary Papers}

Return of Number of Agrarian Outrages committed in Ireland reported to Inspector General of Royal Irish Constabulary, April 1882, H.C. 1882, (182), lv, 41-4, (5 May 1882).

\section{Printed Primary Sources}

O’Brien, R. Barry, The Life of Charles Stewart Parnell 1846-91, (2 vols., New York, Harper and Brothers), 1898.

Butt, Isaac, Home government for Ireland: Irish federalism, its meaning, its objects and its hopes (Dublin, Falconer, 1870; $3^{\text {rd }}$ Ed., Falconer, Dublin, 1871). https://ia802605.us.archive.org/34/items/ homegovernmentfoobuttgoog/homegovernmentfoobuttgoog.pdf [Accessed 5 Aug. 2018].

O'Brien, William, Recollections (New York, The Macmillan Company, 1905).

O'Shea, Katherine, The Uncrowned King of Ireland: Charles Stewart Parnell his love life and Political Life, ([1914] Stroud, Nonesuch Publishing Limited, 2005).

O’Brien, William and Ryan, Desmond, (eds), Devoy's Post Bag, 1871-1928 (2 Vols, Dublin, C.J. Fallon, 1948 and 1954).

\section{Contemporary newspapers}

Irish Examiner

Irish Times

Manchester Guardian

The Nation

United Irishman

Wexford People

\section{Secondary Sources}

Bew, Paul, Ireland, The Politics of Enmity, 1789-2006 (Oxford, Oxford University Press, 2007).

Bull, Philip “O'Brien, William”, in McGuire, James and Quinn, James, (ed), Dictionary of Irish Biography (Cambridge, Cambridge University Press, 2009). (http://dib.cambridge.org/ viewReadPage.do?articleId=a6503). 
Callanan, Frank, “'In the names of God and dead generations”: Nationalism and Republicanism in Ireland' in Richard English and Joseph Morrison Skelly (eds), Ideas Matter, Essays in honour of Conor Cruise O'Brien (Dublin, Poolbeg, 1998) pp. 109-22.

Comerford, R.V., Charles J. Kickham, Portmarnock, Co. Dublin, Wolfhound Press, 1979.

Comerford, R.V., "Isaac Butt and the home rule party, 1870-77", in W.E. Vaughan, (ed.), A New History of Ireland VI, Ireland Under the Union 1870-1821 (Oxford, Oxford University Press, 1989), pp. $1-25$.

Comerford, R.V., "The Land War and the Politics of Distress, 1877-82", in W.E. Vaughan, (ed.), A New History of Ireland VI, Ireland Under the Union 1870-1821 (Oxford, Oxford University Press, 1989), pp. 26-52.

Cruise O’Brien, Conor, Parnell and his Party 1880-1890 (London, Faber \& Faber, 1957, 2015).

Garvin, Tom, The Evolution of Irish Nationalist Politics, (Dublin, Gill and Macmillan, $2^{\text {nd }}$ ed. 1983).

Foster, R.F., Charles Stewart Parnell, The Man and his Family (Hassocks, Sussex, Harvester Press, $2^{\text {nd }}$ ed. 1979).

Foster, R.F., Modern Ireland 1600-1972 (London, Penguin, 1989).

Jackson, Alvin, Home Rule: An Irish History 1800-2000 (Oxford, Oxford University Press, 2003).

Jackson, Alvin, Ireland 1898-1998 (Oxford, Blackwell Publishers, 1999).

Kirkpatrick, Richard W., "Origins and development of the land war in mid-Ulster1879-85" in R.A.J. Hawkins \& F.S.L. Lyons (eds), Ireland under the Union, Varieties of Tension (Oxford, Oxford University Press, 1980), pp $201-36$.

Lyons, F.S.L., Charles Stewart Parnell, (London, Fontana, 1978),

Lyons, F.S.L., Davitt and the Irish Revolution, 1846-82 (Oxford, Clarendon Press, 1982).

Lyons, F.S.L., “The Political Ideas of Parnell”, Historical Journal, Vol. 16, No. 4 (Dec. 1973),

Cambridge, Cambridge University Press, pp. 749-775.

Maye, Brian, “A byword for political betrayal - An Irishman's Diary on William Keogh”, Irish Times, 11 Dec. 2017, https://wwsw.irishtimes.com/opinion/a-byword-for-political-betrayal-anirishman-s-diary-on-william-keogh-1.3322047 [5 Aug. 2018].

McConnel, James, "Fenians at Westminster: The Edwardian Irish Parliamentary Party and the Legacy of the New Departure", Irish Historical Studies, Vol. 34, No. 133 (May 2004), pp. 42-64.

McConnel, James, “Jobbing with Tory and Liberal': Irish Nationalists and the Politics of Patronage 1880-1914”, Past \& Present, No. 188 (Aug. 2005), pp. 105-131,

Moody, T.W., Davitt and the Irish Revolution 1846-82 (Oxford, Oxford University Press, 1982).

O'Day, Alan, Parnell and the First Home Rule Episode 1884-87, (Dublin, Gill and Macmillan, 1986).

O'Day, Alan, The English Face of Irish Nationalism, Parnellite Involvement in British Politics, 1880-86, (Dublin, Gill and MacMillan, 1977).

Rynne, Frank, "Permanent revolutionaries: the IRB and the Land war in West Cork", in McConnel, James \& McGarry, Fearghal (eds), The Black Hand of Republicanism: Fenianism in Modern Ireland (Dublin, Irish Academic Press, 2009), pp. 55-71.

Rynne, Frank, "Redressing Historical Imbalance: The Role of Grassroots Leaders Richard Hodnett and Henry O'Mahony in the Land league Revolution in West Cork, 1879-82" in Brain Casey, (ed) 
Defying the Law of the Land: Agrarian Radicals in Irish History (Dublin, The History Press, 2013), pp. 133-153.

Rynne, Frank, “The Great Famine in Nationalist and Land League propaganda 1879-1882", Mémoire(s), identité(s), marginalité(s) dans le monde occidental contemporain, 12 | 2015, https:// journals.openedition.org/mimmoc/1864, [12 Aug. 2018].

Walker, Brian M., “The Land Question and Elections in Ulster 1868-1886" in Samuel Clark and J.S. Donnelly Jnr., Violence and Political Unrest, 1780-1914 (Manchester, Manchester University Press, 1983).

Whelehan, Niall, Irish Nationalism and Political Violence in the Wider World, 1867-1900 (Cambridge, Cambridge University Press, 2012).

Vaughan, W.E., (ed.) A New History of Ireland VI, Ireland Under the Union 1870-1821 (Oxford, Oxford University Press, 1989).

Vaughan, W.E., Murder Trials in Ireland 1836-1914 (Dublin, Four Courts Press, 2009).

\section{Unpublished thesis}

Rynne, Frank, The Irish Republican Brotherhood and the Land War in Skull Co. Cork, 1879-82, Unpublished thesis, Trinity College Dublin, 2014.

\section{NOTES}

1. Charles Stewart Parnell, speech, Cork, 21 January 1885, Irish Examiner, 22 Jan. 1885.

2. Alvin Jackson, Home Rule: An Irish History 1800-2000 (Oxford, Oxford University Press, 2003), p. 53.

3. Ibid., citing Richard Shannon, Gladstone: Heroic Minister,1865-1898 (London, Allen Lane, 1999), p. 352.

4. William O'Brien lecture to the Mallow Library Society, 6 Feb. 1885, Irish Examiner, 9 Feb. 1885.

5. Jackson, Home Rule, p. 55.

6. Brian Maye, “A byword for political betrayal - An Irishman's Diary on William Keogh”, Irish Times, 11 Dec. 2017,

https://www.irishtimes.com/opinion/a-byword-for-political-betrayal-an-irishman-s-diary-onwilliam-keogh-1.3322047, [accessed 5 Aug. 2018].

7. R.V. Comerford, "Isaac Butt and the home rule party, 1870-77", in W. E. Vaughan (ed.), A New History of Ireland VI, Ireland Under the Union 1870-1821 (Oxford: Oxford University Press, 1989) pp. $1-2$.

8. Ibid, p. 3; Isaac Butt, Home government for Ireland: Irish federalism, its meaning, its objects and its hopes, ([1870] $3^{\text {rd }}$ ed. Dublin, Falconer, 1871), p.8 available on

https://ia802605.us.archive.org/34/items/homegovernmentfoobuttgoog/ homegovernmentfoobuttgoog.pdf, accessed 5 Aug. 2018].

9. While at first the IRB leadership cooperated with the Home Rule movement the IRBSC passed a resolution in August 1876 demanding that all members "withdraw from it their active co-operation", this led to four members of the IRBSC, Thomas O'Connor Power, Joseph Biggar, John Barry and Patrick Egan, resigning or being expelled from the IRBSC. R.V. Comerford, Charles J. Kickham, (Portmarnock, Co. Dublin, Wolfhound Press, 1979), p. 132.

10. Conor Cruise O'Brien, Parnell and his Party 1880-1890 (London, Faber \& Faber, [1957] 2015), p. 23. 
11. Roy F. Foster, Charles Stewart Parnell, The Man and his Family (Hassocks, Sussex, Harvester Press, $2^{\text {nd }}$ ed. 1979), p. 145.

12. The terms Nationalist, Advanced Nationalist were synonymous with Fenian at this time: see Frank Callanan, “'In the names of God and dead generations': Nationalism and Republicanism in Ireland", in Richard English and Joseph Morrison Skelly (eds), Ideas Matter, Essays in honour of Conor Cruise O'Brien, (Dublin, Poolbeg, 1998), pp 110-114.

13. F.S.L. Lyons, Charles Stewart Parnell (London, Fontana, 1978), p. 80.

14. Frank Rynne, "The Irish Republican Brotherhood and the Land War in Skull Co. Cork, 1879-82" (unpublished thesis, Trinity College Dublin, 2014), pp 68-72.

15. Richard W. Kirkpatrick, "Origins and development of the land war in mid-Ulster1879-85", in R.A.J. Hawkins \& F.S.L. Lyons (eds), Ireland under the Union, Varieties of Tension (Oxford, Oxford University Press, 1980), p. 202.

16. T.W. Moody, Davitt and the Irish Revolution, 1846-82 (Oxford, Clarendon Press, 1982), p 545. Patrick Egan treasurer of the land League estimated total receipts of $£ 245,000$ of which a balance of $£ 31,900$ was left and presumably this was the sum which Parnell took control of prior to founding the National League.

17. Frank Rynne, "Permanent revolutionaries: the IRB and the Land war in West Cork", in James McConnel \& Fearghal McGarry (eds), The Black Hand of Republicanism: Fenianism in Modern Ireland (Dublin, Irish Academic Press, 2009), p. 62.

18. Frank Rynne, "The Great Famine in Nationalist and Land League propaganda 1879-1882", Mémoire(s), identité(s), marginalité(s) dans le monde occidental contemporain, $12 \mid 2015$, https:// journals.openedition.org/mimmoc/1864, accessed 12 Aug. 2018.

19. Protection of Persons and Property (Ireland) Act, 188144 Vict. c.4 (2. Mar 1881).

20. The Irish Church Act 1869, 32 \& 33 Vict., c. 42 [26 July 1869], Landlord and Tenant (Ireland) 1870, Vict., 33 \& 34, c.46 [1st August 1870].

21. The government referenced agrarian violence and crime as "Outrages" and discussions at parliament regarding agrarian crime were published in Hansards under the heading heading "Crime and Outrage" see for example Hansard, Parliamentary Debates. third series, 3 July 1882 vol. 271, cc. 1261-2. The term was a holdover from the Crime and Outrage Act 1847 which was replaced in 1857 by another coercion act the Peace Preservation Act 1857. See W.E. Vaughan, Murder Trials in Ireland 1836-1914 (Dublin, Four Courts Press, 2009), p. 17. Monthly reports on agrarian outrages were published under the provisions of various coercion acts; see for example "Return of Number of Agrarian Outrages committed in Ireland reported to Inspector General of Royal Irish Constabulary", April 1882, in Hansard, H. C.. 1882, (182), lv, 41-4, (5 May 1882).

22. Paul Bew, Ireland, The Politics of Enmity, 1789-2006 (Oxford, Oxford University Press, 2007), p.329.

23. On release from prison after incarceration under the PPP Act, many local activists signed their letters with their name and the term "Ex-Suspect". Being arrested under the act proved an intransigent adherence to Irish Advanced Nationalism. E.g. Letter Henry O'Mahony to Anna Parnell, 18 Nov. 1881, Documents relating to the Ballydehob case, National Archives of Ireland, Irish National League papers, box 10.

24. Katherine O'Shea, The Uncrowned King of Ireland: Charles Stewart Parnell, his Love Life and Political Life (Stroud, Nonesuch Publishing Limited, [1914], 2005) pp. 144-51; F.S.L. Lyons, Charles Stewart Parnell (London, Fontana, 1978), pp. 189-206.

25. Alan O'Day, The English Face of Irish Nationalism, Parnellite Involvement in British Politics, 1880-86 (Dublin, Gill and MacMillan, 1977), p. 59 citing the original letter Parnell sent via William O'Shea which is in the Gladstone papers, Add. MS.44159.

26. Ibid.

27. Irish Times, 3 May 1882; Lyons, Parnell, p. 204

28. Lyons, Parnell, p.205; The Manchester Guardian, 5 May 1882 p. 5 
29. Ibid.

30. Lyons, Parnell, p. 207; R.V. Comerford, "The Politics of Distress", p. 49.

31. Paul Bew, Ireland the Politics of Enmity, pp.335-6; see note 147 on p.336 for brief discussion and references.

32. William Mackey Lomansey was not only a close confident of John Devoy, he had met Parnell and was later blown up in an attempt to plant a bomb in London. See R.V. Comerford, "The Politics of Distress", p. 50

33. Niall Whelehan, Irish Nationalism and Political Violence in the Wider World, 1867-1900 (Cambridge, Cambridge University Press, 2012), p. 89.

34. Ibid., p. 257.

35. T.W. Moody, Davitt and the Irish Revolution, p. 534.

36. Ibid., pp. 534-5.

37. Alvin Jackson, Ireland 1898-1998 (Oxford, Blackwell Publishers, 1999), p. 124.

38. Ibid.

39. Bew, Ireland the Politics of Enmity, p. 340.

40. Ibid., p. 3.

41. Conor Cruise O'Brien, Parnell and his Party, p. 127.

42. Ibid., p. 129.

43. Ibid. p.128.

44. Ibid., p. 84 citing The Nation, 28 Oct. 1882.

45. Philip Bull, "O'Brien, William", in James McGuire and James Quinn (eds), Dictionary of Irish Biography (Cambridge, Cambridge University Press, 2009).

(http://dib.cambridge.org/viewReadPage.do?articleId=a6503, accessed 12 August 2018)

46. William O'Brien, Recollections (New York, The Macmillan Company, 1905), p. 473.

47. Ibid. Various examples of proceedings against O'Brien for libel were widely reported in the press furthering United Ireland's image as a staunch defender of nationalist interests; see e.g. Irish Examiner, 5 Nov. 1883; The Nation, 9 Aug.1884.

48. Wexford People, 27 Dec. 1882.

49. William O'Brien, “Accusing Spirits”, United Irishman, 23 December 1882: R. Barry O'Brien, The Life of Charles Stewart Parnell 1846-91, 2 vols., (New York, Harper and Brothers), ii, p. 2.

In March 2018 the Irish government recommended a posthumous pardon for Myles Joyce who was executed in December 1882, he was pardoned in the following month; see Irish Times, 29 Mar. 2018

https://www.irishtimes.com/news/crime-and-law/maamtrasna-murders-relatives-welcomepardon-recommended-for-myles-joyce-1.3444951 and Irish Times, 4 April 2018, https:// www.irishtimes.com/news/ireland/irish-news/president-signs-pardon-for-man-hanged-formaamtrasna-murders-1.3450687, accessed 12 August 2018.

50. John Boyle O'Reilly to John Devoy, 28 April 1883, in William O'Brien and Desmond Ryan (eds), Devoy's Post Bag, 1871-1928, 2 vols. (Dublin, C.J. Fallon, 1948 and 1954), ii, p. 194.

51. R.F. Foster, Modern Ireland, 1600-12 (London, Penguin, 1989), pp. 417-8.

52. Ibid., p. 418.

53. Ibid.

54. Alan O'Day, The English Face of Irish Nationalism: Parnellite Involvement in English Politics, 1880-86 (Dublin, Gill \& MacMillan, 1977), p. 85.

55. Ibid.

56. Ibid.

57. Ibid., p.122; Cruise O'Brien, Parnell and His Party, pp.85-6 (see footnote 3).

58. Bew, Ireland the Politics of Enmity, p.341.

59. Lyons, Parnell, p.245. 
60. Ibid., pp.253-4. Citing a letter from the President of the Catholic seminary Maynooth, Dr. W.J. Walsh to Cardinal McCabe, 12 Feb. 1884.

61. Jackson, Ireland 1898-1998, p. 126. See also Cruise O’Brien, Parnell and His Party, pp. 89-90.

62. O’Day, The English Face of Irish Nationalism, p. 129.

63. Ibid., pp. 131-2.

64. Ibid., p. 132.

65. Ibid., pp. 139-152.

66. Cruise O'Brien, Parnell and His Party, pp 141-2. For a full discussion of Irish nationalists and patronage at Westminster from 1880-1914 see James McConnel, “'Jobbing with Tory and Liberal': Irish Nationalists and the Politics of Patronage 1880-1914." in Past \& Present, No. 188 (Aug. 2005), pp. 105-13.

67. O'Day, The English Face of Irish Nationalism, p. 77.

68. McConnel, “'Jobbing with Tory and Liberal"', p. 109, citing Alan O'Day, "The Irish Parliamentary Party and British Politics, 1880-1886", (Univ. of London, Ph.D. thesis, 1971), pp. 177-86.

69. Cruise O'Brien, Parnell and His Party, pp. 86-7. The latter point on representation citing Parnell in United Irishman, 29 Mar. 1884. See also Representation of the People Act 1884 (48 \& 49 Vict. c. 3) [6 Dec. 1884].

70. The Redistribution of Seats Act 1885 (48 \& 49 Vict., c. 23) [25 June 1885].

71. Cruise O’Brien, Parnell and His Party, p. 87.

72. O'Day, The English Face of Irish Nationalism, p. 77.

73. For a full discussion of the period see Alan O'Day, Parnell and the First Home Rule Episode 1884-87 (Dublin, Gill and Macmillan, 1986), pp. 1-121.

74. Ibid., p. 91 quoting The Times, 19 Sept. 1885.

75. F.S.L. Lyons, “The Political Ideas of Parnell”, Historical Journal, Vol. 16, No. 4 (Dec. 1973), pp. 755-6 citing The Nation, 5 Sept.1885.

76. Lyons, “The Political Ideas of Parnell”, p. 301.

77. Ibid.

78. Ibid., Note 16 citing The Nation, 22 Mar. 1884.

79. Foster, Modern Ireland, p. 417.

80. Tom Garvin, The Evolution of Irish Nationalist Politics (Dublin, Gill and Macmillan, $2^{\text {nd }}$ ed. 1983), p. 80; Cruise O'Brien, Parnell and his Party, p. 133. Cruise O'Brien suggests one less branch in January 1886 citing a government report and O'Brien also lists one less branch as the highest number of branches, 1,285 and 1,286 respectively by July 1886 . Note that both were using the same archival source, the INL Papers now held at the Irish National Archives (previously known as the State Papers Office).

81. Cruise O'Brien, Parnell and his Party, p. 130.

82. Ibid.

83. Ibid., p.131.

84. James J. O'Kelly, MP to John Devoy, 17 Sept. 1885, O'Brien and Ryan (eds), Devoy's Post Bag, p. 265.

85. Ibid.

86. Cruise O'Brien, Parnell and his Party,., p. 129.

87. James J. O'Kelly, MP to John Devoy, 17 Sept. 1885, O’Brien and Ryan (eds), Devoy's Post Bag., p. 265.

88. Ibid.

89. Ibid., p. 266.

90. O’Kelly to Devoy, 2 Dec. 1885, Ibid p. 267.

91. James McConnel, “'Fenians at Westminster': The Edwardian Irish Parliamentary Party and the Legacy of the New Departure", Irish Historical Studies, Vol. 34, No. 133 (May 2004), pp. 42-64. 
92. Frank Rynne, "The Irish Republican Brotherhood and the Land War in Skull, Co. Cork, 1879-82" Unpublished Thesis, Trinity College Dublin, 2014, p. 208; Frank Rynne, "Redressing Historical Imbalance: The Role of Grassroots Leaders Richard Hodnett and Henry O'Mahony in the Land league Revolution in West Cork, 1879-82" in Brian Casey (ed), Defying the Law of the Land: Agrarian Radicals in Irish History (Dublin, The History Press, 2013), p.152.

93. McConnel, "Fenians at Westminster", p. 54.

94. Irish Times, 19 Dec. 1885.

95. Ibid, 30 Nov 1885.

96. Ibid., 19 Dec. 1885.

97. Brian M. Walker, “The Land Question and Elections in Ulster 1868-1886", in Samuel Clark and J.S. Donnelly Jnr., Violence and Political Unrest, 1780-1914 (Manchester, Manchester University Press, 1983), pp. 263.

98. Bew, Ireland the Politics of Enmity, p. 352.

99. Foster, Modern Ireland, p. 419.

\section{ABSTRACTS}

In the aftermath of the Land War, Parnell's fortunes were far from assured. Having courted Advanced Nationalist anti-English rhetoric along with his Land League associates, he had struck a secret deal with the United Kingdom government. This article examines the changing fortunes of Parnell following the Land War 1879-82 and the establishment of the more autocratic Irish National League. It shows the role of the Catholic Church in Irish politics and the Catholic hierarchy's ability to ignore Rome and follow their flock in national political matters. The balancing of the competing forces of Advanced Nationalism and Catholic political representation at Westminster is examined. Furthermore, it shows through a historiographic analysis that concurrent with the rise of Parnellism events leading up to the 1885 general election cemented political sectarianism into the fabric of Irish politics.

Immédiatement après la Guerre des Terres, le destin politique de Parnell était loin d'être établi. Après avoir adopté la rhétorique anti-anglaise du nationalisme extrême avec ses associés de la Ligue Agraire, il passa un pacte secret avec le gouvernement britannique. Cet article étudie le destin changeant de Parnell après la Guerre des Terres de 1879-1882 et la mise en place d'une Ligue Nationale Irlandaise, plus autocratique. Il montre aussi le rôle joué par l'Église catholique dans la vie politique irlandaise et la capacité de la hiérarchie ecclésiale irlandaise à s'affranchir de l'autorité papale pour suivre les fidèles irlandais en matière de politique nationale. Le rapport de force qui put exister entre les forces rivales que furent le nationalisme extrême et la représentation parlementaire catholique est examiné. Une analyse historiographique contribue à souligner qu'en parallèle de l'avènement du "parnellisme », les événements qui menèrent à 1885 permirent au sectarisme religieux de s'enraciner durablement dans la vie politique irlandaise. 


\section{INDEX}

Mots-clés: question agraire en Irlande, Charles Stewart Parnell, nationalisme extrême, Ligue Nationale Irlandaise, parti parlementaire irlandais

Keywords: Irish land question, Charles Stewart Parnell, advanced nationalism, Irish National League, Irish Parliamentary Party

\section{AUTHOR}

\section{FRANK RYNNE}

Frank Rynne is a Senior Lecturer in British Studies at the University of Cergy-Pontoise. He studied at Trinity College Dublin where his PhD thesis "Permanent Revolutionaries: the Irish Republican Brotherhood and the Land War in Skull, Co. Cork 1879-82" was supervised by W.E. Vaughan. He co-edited La Grande Famine en Irlande, 1845-52 (Atlande, 2015). Frank Rynne has contributed to numerous journals and books on subjects relating to Irish revolutionaries in the 19th century. He recently participated in the award-winning Atlas of the Irish Revolution, (Cork, UCC Press 2018). He is a member of the research group Agora at the University of Cergy-Pontoise and is an associate member of PRISMES at the University Sorbonne Nouvelle.

Frank Rynne est maître de conférences en civilisation britannique à l'Université de CergyPontoise. Ancien étudiant de Trinity College Dublin, il y a rédigé une thèse portant sur l'Irish Republican Brotherhood et la guerre de la terre à Skull (co. Cork), 1879-1882, sous la direction de W.E. Vaughan. Il a codirigé La Grande Famine en Irlande, 1845-52 (Atlande, 2015). F. Rynne est l'auteur de nombreux articles et chapitres d'ouvrages sur les révolutionnaires irlandais au XIX ${ }^{\mathrm{e}}$ siècle - et très récemment, dans l'Atlas of the Irish Revolution, (Cork, UCC Press 2018). Il est membre du groupe de recherche Agora à l'Université de Cergy-Pontoise, et chercheur associé à PRISMES, Université Sorbonne-Nouvelle. 